Journal of Extension Education

Vol. 28 No. 3, 2016

DOI:https: //doi.org/10.26725/JEE.2016.3.28.5672-5679

\title{
Relative importance of Farmers' Characteristics in Predicting their Knowledge about Indigenous Agricultural Practices
}

\section{A. Sakeer Husain ${ }^{1}$, M. Sundaramari ${ }^{2}$ and J. Sreekumar ${ }^{3}$}

\begin{abstract}
This study was conducted to identify the farmers' characteristics that act as factors in influencing their knowledge on indigenous agricultural practices. The study was conducted in the state of Kerala among 40 farmers each of ten selected horticultural crops. Step wise regression analysis and multiple linear regression analysis were employed to identify the influencing factors. The study revealed that age, farm power status, innovativeness, rational orientation, communication status, and social participation status positively influence knowledge of farmers on indigenous agricultural practices whereas material status, educational status, and family status were the important characteristics of farmers negatively influencing the knowledge of indigenous practices.
\end{abstract}

Keywords : Traditional agricultural practices, Indigenous Technical Knowledge, Knowledge determinants, Kerala

\section{INTRODUCTION}

Indigenous knowledge (IK) is the knowledge that the people in a given community have developed over time and continue to develop (IIRR, 1996). It is based on experience, often tested over centuries of use, adapted to local culture and environment, and it is dynamic and changing. Any community possesses IK- rural and urban, settled and nomadic, original inhabitants and migrants. According to IIRR (1996), indigenous knowledge in agriculture may be classified into different types such as information, practices and technologies, beliefs, tools, materials, experimentation, biological resources, human resources, education, and communication.

Indigenous knowledge being the knowledge of local people is important in many ways, mainly due to the unique nature of such technologies/practices. IK is the social capital of the poor, their main asset to invest in the struggle for survival, to produce food, to provide for shelter, or to achieve control of their own lives. Prasad and Ramaprasad (2006) reiterated that the best traditional practices serve as a knowledge pool for the small and marginal farmers without

1.Associate Professor, Kerala Agricultural University, Thrissur, Kerala, India 2. Professor, Gandhigram Rural Institute, Gandhigram, Tamil Nadu, India and 3. Principal Scientist, Central Tuber Crops Research Institute (ICAR), Thiruvananthapuram, Kerala, India 
high risk. However, the lacuna is lack of effective communication to disseminate this knowledge to the resource poor farmers.

Various studies have revealed that the awareness level of traditional knowledge is declining at an alarming rate. But this knowledge coupled with biological diversity is vital for the survival of mankind, especially for the future generations. Before making efforts to perk up the knowledge and adoption of various practices, attempts should be made not only to analyse the validity of the practices, but also to ascertain the present status of the target group with regard to their knowledge. Hence, it is worthwhile to analyse the knowledge level of people on indigenous practices in all spheres of life, including the agricultural sector, and also to analyse the factors that may determine knowledge. In this backdrop, the present study was undertaken with the objective of identifying the factors that may influence the knowledge of farmers about Indigenous Technical Knowledge in agriculture.

\section{METHODOLOGY}

The study was conducted among the farmers of the state of Kerala. It was decided to have the analysis on the knowledge of farmers among horticultural crops, since they contribute more than 80 percent of the cultivated crops in Kerala. After careful analysis of the available literature and keeping the objectives in view, more of qualitative and attitudinal variables were selected for the study. Most of the selected variables were of expost facto in nature and the researcher had very little chance to control them. Hence an expost facto research design was used for the present study.

Among the five agro climatic zones of Kerala viz. Southern zone, Central zone, Northern zone, High altitude zone, and Problem area zone., excluding the problem area zone, which is scattered in many districts of Kerala, one district each, from the other four agro climatic zones was purposively selected based on the larger coverage of horticultural crops. Thus, four districts out of the fourteen districts of Kerala were selected. From each district, two blocks each having predominant area under horticultural crops were selected purposively, and from each block two village panchayats were selected purposively. Thus, a total of 16 village panchayats spread over the state of Kerala were selected.

Based on the area under cultivation of various horticultural crops in the study area, the economic importance of the crops and the number $\&$ importance of indigenous practices collected, ten crops were selected for the study, which include coconut, banana, amaranth, vegetable cow pea, bitter gourd, elephant foot yam, pepper, ginger, arecanut and coffee. In addition, indigenous practices on general agriculture were also included. The knowledge of concerned farmers on indigenous practices of various crops was assessed. 
It was intended to approach 40 farmers for the selected ten crops, and thus a total of 400 farmers formed the sample of the study. For each of the 10 crops, ten farmers were required to be contacted from each district, except in the case of coffee. For the high elevation crop viz. coffee, it was decided to contact 40 farmers exclusively from Wayanad district. Within a district, five farmers each for each crop from each of the selected block were identified. When respondents were selected from the village panchayats, proportionate random sampling was used i.e. proportionate to the area under cultivation of each crop.

Accordingly, after collecting the list of farmers from the concerned Agricultural offices (Krishibhavan) of the Department of Agriculture in each of the earlier selected 16 village panchayats, farmers were contacted at random. When a total of 127 farmers were contacted, sufficient responses (40 set of responses in each crop) were obtained, since many of the selected farmer respondents had been cultivating one or more of the selected crops. The crop-wise and villagewise distribution of the farmers selected for the study is given in Table 1 .

Table 1.

Crop wise and Village wise Distribution of Farmer Respondents

\begin{tabular}{|c|c|c|c|c|c|c|c|c|c|c|c|c|c|c|}
\hline \multirow[b]{2}{*}{$\begin{array}{l}\text { S1. } \\
\text { No. }\end{array}$} & \multirow[b]{2}{*}{ 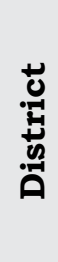 } & \multirow[b]{2}{*}{ 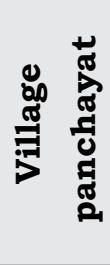 } & \multicolumn{11}{|c|}{ Number of farmer respondents contacted (Crop wise) } & \multirow[b]{2}{*}{$\begin{array}{c}\text { Actual } \\
\text { Number } \\
\text { contacted }\end{array}$} \\
\hline & & & $\begin{array}{l}\stackrel{3}{3} \\
0 \\
0 \\
0\end{array}$ & 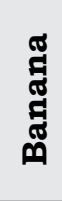 & 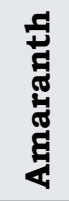 & 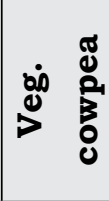 & 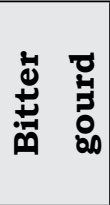 & 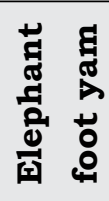 & a & 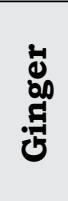 & 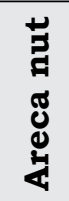 & d્屯 & $\begin{array}{l}\text { శే } \\
\text { \& }\end{array}$ & \\
\hline \multirow{4}{*}{1.} & \multirow{4}{*}{ I } & 1 & 3 & 2 & 2 & 2 & 2 & 3 & 3 & 3 & 2 & --- & 22 & 6 \\
\hline & & 2 & 2 & 3 & 3 & 3 & 3 & 2 & 2 & 2 & 3 & --- & 23 & 7 \\
\hline & & 3 & 2 & 3 & 4 & 4 & 4 & 2 & 2 & 3 & 2 & --- & 26 & 9 \\
\hline & & 4 & 3 & 2 & 1 & 1 & 1 & 3 & 3 & 2 & 3 & --- & 19 & 8 \\
\hline \multirow{4}{*}{2.} & \multirow{4}{*}{ II } & 1 & 2 & 3 & 3 & 3 & 3 & 2 & 2 & 3 & 2 & --- & 23 & 6 \\
\hline & & 2 & 3 & 2 & 2 & 2 & 2 & 3 & 3 & 2 & 3 & --- & 22 & 7 \\
\hline & & 3 & 2 & 2 & 2 & 2 & 2 & 3 & 3 & 2 & 2 & --- & 20 & 8 \\
\hline & & 4 & 3 & 3 & 3 & 3 & 3 & 2 & 2 & 3 & 3 & --- & 25 & 7 \\
\hline \multirow{4}{*}{3.} & \multirow{4}{*}{ III } & 1 & 3 & 2 & 3 & 2 & 2 & 2 & 2 & 3 & 2 & --- & 21 & 7 \\
\hline & & 2 & 2 & 3 & 2 & 3 & 3 & 3 & 3 & 2 & 3 & --- & 24 & 6 \\
\hline & & 3 & 2 & 2 & 2 & 2 & 2 & 3 & 3 & 2 & 3 & --- & 21 & 7 \\
\hline & & 4 & 3 & 3 & 3 & 3 & 3 & 2 & 2 & 3 & 2 & --- & 24 & 6 \\
\hline \multirow{5}{*}{4.} & \multirow{4}{*}{ IV } & 1 & 2 & 2 & 2 & 2 & 2 & 3 & 2 & 3 & 3 & 10 & 31 & 10 \\
\hline & & 2 & 3 & 3 & 3 & 3 & 3 & 2 & 3 & 2 & 2 & 10 & 34 & 11 \\
\hline & & 3 & 3 & 2 & 3 & 3 & 3 & 2 & 3 & 2 & 3 & 10 & 34 & 12 \\
\hline & & 4 & 2 & 3 & 2 & 2 & 2 & 3 & 2 & 3 & 2 & 10 & 31 & 10 \\
\hline & & & 40 & 40 & 40 & 40 & 40 & 40 & 40 & 40 & 40 & 40 & 40 & 127 \\
\hline
\end{tabular}


The objective of the study necessitated knowledge of farmers about indigenous horticultural practices as the dependent variable of the study. Based on extensive review of literature on the subject, and consultation with the agricultural extension scientists, followed by screening out variables by judges rating, 13 variables with a relevancy score above the mean relevancy score (4.2) were identified, as followed by Nataraju (1991) and Sundaramari (2001). The identified variables were: age, farming experience, livestock possession, socio-economic status, extension agency contact, mass media exposure, fatalism, decision making ability, innovativeness, rational orientation, environmental orientation, belief in traditional agriculture, and attitude towards indigenous knowledge. To study the influence in detail, the subcomponents of socio economic status such as educational status, family status, occupational status, farm status, social participation status, communication status, farm power status, material status were also used in the analysis along with the independent variables, replacing the socio economic status

Step wise regression analysis was done to know the relative effect of the independent variables in the study in predicting the dependent variable and for elimination of unimportant ones. Thus it gave information regarding the best subset of components and the relative contribution of each of these components in the variation in dependent variables after eliminating unimportant components. Here, the step wise (forward) regression analysis was done using the criterion, Adjusted R-squared for selecting the best model among all possible models. This analysis was done at two stages. Accordingly models were suggested in each case.

Multiple linear regression analysis was carried out to determine the combined contributions of the independent variables considered (contribution of each model) for the variations in the dependent variable. It was also meant to find out the variables which have contributed significantly for the changes in the dependent variable.

To find out the extent of influence of independent variables on the dependent variable, knowledge of Indigenous Agricultural Practices (IAPs) step wise regression analysis and multiple linear regression analysis were performed. The step wise (forward) regression analysis was done here so as to find out the best model among different models predicting the dependent variable. It is an accumulated analysis of deviance resulting from stepwise regression starting with no candidate terms in the model. The criterion used in this analysis was adjusted R-squared. After identifying the best model, multiple linear regression analysis was subsequently done in the particular model to know the extent of influence of different independent variables. 
Relative importance of Farmers' Characteristics in Predicting their Knowledge about Indigenous Agricultural Practices

\section{FINDINGS AND DISCUSSION}

As mentioned, the relative importance of independent variables in predicting the knowledge of indigenous agricultural practices (IAPs) was analysed using regression analysis. The step wise (forward) regression analysis to identify the best knowledge model had suggested the final model as follows:

Knowledge of IAPs $=$ Constant + age + livestock possession + belief in traditional agriculture + innovativeness + socio-economic status + extension agency contact + decision making ability (Knowledge Model- I)

To know the relative importance of these variables in predicting the knowledge on IAPs, multiple linear regression analysis was done on this model, and the results are given in Table 2.

\section{Table 2.}

Multiple Linear Regression Analysis of Knowledge Mode1 - I

\begin{tabular}{|c|l|c|c|c|c|}
\hline $\begin{array}{c}\text { S1. } \\
\text { No. }\end{array}$ & \multicolumn{1}{|c|}{ Particulars } & $\begin{array}{c}\text { Regression } \\
\text { coefficients }\end{array}$ & $\begin{array}{c}\text { Standard } \\
\text { Error }\end{array}$ & $\begin{array}{c}\mathbf{t} \\
\text { value* }^{*}\end{array}$ & $\begin{array}{c}\mathbf{t} \\
\text { probability }\end{array}$ \\
\hline 1. & Constant & 18.59 & 6.47 & 2.87 & 0.005 \\
2. & Age & 0.3360 & 0.0709 & 4.74 & $<.001$ \\
3. & Livestock possession & 1.544 & 0.422 & 3.66 & $<.001$ \\
4. & Belief in traditional agriculture & 3.98 & 1.05 & 3.78 & $<.001$ \\
5. & Innovativeness & 4.16 & 1.26 & 3.29 & 0.001 \\
6. & Socio-economic status & 0.0792 & 0.0413 & 1.92 & 0.058 \\
7. & Extension agency contact & 0.233 & 0.113 & 2.05 & 0.042 \\
8. & Decision making ability & -0.306 & 0.263 & 1.16 & 0.247 \\
\hline
\end{tabular}

$\mathrm{F}=14.79 \quad$ F pr. $<.001 \quad \mathrm{R}^{2}=0.434 \quad \mathrm{SE}=7.90$

* $\mathrm{df}=119$

Table 2 reveals that the variables such as age, livestock possession, belief in traditional agriculture, and innovativeness had the major role in developing the knowledge of IAPs at $1 \%$ level of significance, whereas extension agency contact had influence on knowledge level, which is significant at $5 \%$ level. But this model explained only
$43.40 \%$ of the total variation. Hence, instead of socio-economic status, all the constituent variables of socio-economic status were included along with other independent variables, and a step wise regression analysis was done again, which has given the following final model.

Knowledge of IAPs $=$ Constant + age + farm power status + material status + 
innovativeness + belief in traditional agriculture + occupational status + rational orientation + educational status + communication status + livestock possession + social participation status
+ family status + mass media exposure + farm status (Knowledge Model- II)

The result of multiple regression analysis done on this model is given in Table 3.

Table 3.

Multiple Linear Regression Analysis of Knowledge Model - II

$(\mathbf{n}=127)$

\begin{tabular}{|c|c|c|c|c|c|}
\hline $\begin{array}{l}\text { S1. } \\
\text { No. }\end{array}$ & Particulars & $\begin{array}{l}\text { Regression } \\
\text { coefficients }\end{array}$ & $\begin{array}{c}\text { Standard } \\
\text { Error }\end{array}$ & $\begin{array}{c}\mathbf{t} \\
\text { value* }\end{array}$ & $\begin{array}{c}\mathbf{t} \\
\text { probability }\end{array}$ \\
\hline 1. & Constant & 35.19 & 9.29 & 3.79 & $<.001$ \\
\hline 2. & Age & 0.3144 & 0.0640 & 4.91 & $<.001$ \\
\hline 3. & Farm power status & 0.380 & 0.115 & 3.31 & 0.001 \\
\hline 4. & Material status & 0.2721 & 0.0663 & 4.11 & $<.001$ \\
\hline 5. & Innovativeness & 3.24 & 1.07 & 3.02 & 0.003 \\
\hline 6. & Belief in traditional agriculture & 1.64 & 1.03 & 1.59 & 0.114 \\
\hline 7. & Occupational status & -1.112 & 0.623 & 1.78 & 0.077 \\
\hline 8. & Rational orientation & 3.51 & 1.26 & 2.78 & 0.006 \\
\hline 9. & Educational status & -3.10 & 1.06 & 2.92 & 0.004 \\
\hline 10. & Communication status & 1.610 & 0.773 & 2.08 & 0.040 \\
\hline 11. & Livestock possession & 0.887 & 0.458 & 1.94 & 0.055 \\
\hline 12. & Social participation status & 1.443 & 0.695 & 2.08 & 0.040 \\
\hline 13. & Family status & -1.339 & 0.550 & 2.44 & 0.016 \\
\hline 14. & Mass media exposure & 0.594 & 0.363 & 1.64 & 0.104 \\
\hline 15. & Farm status & 1.000 & 0.693 & 1.44 & 0.152 \\
\hline
\end{tabular}

The results given in Table 3 reveal that the model explained 60.20 percent of the total variation. Among the variables, age, farm power status, innovativeness, and rational orientation had positive and significant influence while material status and educational status had negative and significant influence on 
Relative importance of Farmers' Characteristics in Predicting their Knowledge about Indigenous Agricultural Practices

knowledge at 1 per cent level. At the same time, communication status, and social participation status had shown significant positive influence at 5 per cent level, and family status had shown significant negative influence at 5 percent level. It is quite natural that the age of farmers may be expected to have significant positive influence on the knowledge about indigenous practices, as the old farmers are the treasure house of information especially the indigenous knowledge. Hence the saying, "when an old man dies a library is lost'. Similarly farmers with high farm power status, innovativeness and rational orientation would also try to gain more knowledge whether it is about indigenous knowledge or not. The increased communication status and social participation status would also definitely enable the farmers to gain more knowledge on indigenous practices by way of more contact, interaction and communication. On the other hand, when material status, educational status, and family status increase, people will go behind modern, sophisticated, so called advanced technologies, and try to get more information on it, ignoring the old techniques and practices with an intention to get quick results, more profit and to have comfort without considering the advantages of Indigenous Knowledge. Thus the influence of all the independent variables mentioned above has been justifiable and logical.The findings are partly in conformity with those of Jayawardana (2007)

\section{CONCLUSION}

Knowledge is the precursor of adoption; without knowledge and adoption, a practice cannot be propagated. To propagate and promote a practice, careful understanding of the factors that influence the knowledge of farmers and adoption of indigenous technical practices in agriculture is vital. The present study concludes that age, farm power status, innovativeness, rational orientation, communication status, social participation status material status, educational status, and family status were the important characteristics of farmers in influencing the knowledge of indigenous agricultural practices, of which the latter three variables were negatively influencing knowledge. Thus, by improving the social participation status, communication status, innovativeness, rational orientation of farmers as well as operating through aged farmers, knowledge of farmers on indigenous technical knowledge in agriculture can be nurtured.

\section{REFERENCES}

IIRR. (1996). Recording and Using Indigenous Knowledge: A Manual. International Institute of Rural Reconstruction, Silang, Cavite, Philippines. 211p.

Jayawardana, J. K. J. P. (2007). Organic agricultural practices in coconut based homesteads in Thiruvananthapuram district. Unpublished M. Sc. (Ag.) 
thesis, Kerala Agricultural University, Thrissur, India, 124p.

Nataraju, M.S. (1991). Effectiveness of farm magazines- a component analysis. Unpublished Ph.D. thesis, Tamil Nadu Agricultural University, Coimbatore, India.

Prasad, G. K. \& Ramaprasad, V. (2006). Disseminating traditional seed storage practices through people's participation. LEISA INDIA, 8(3): 3435.

Sundaramari, M. (2001). Adoption and perceived effectiveness of indigenous agricultural practices in different farming systems. Unpublished Ph. D. thesis, Gandhigram Rural Institute, Gandhigram, India. 